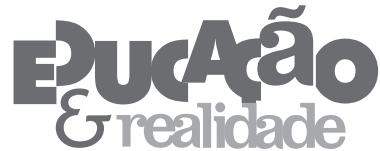

\section{A Experiência Ético- Formativa da Psicanálise e a Interlocução com Kant}

\author{
Simone Alexandre Martins Corbiniano' \\ 'Universidade Federal de Goiás (UFG), Goiânia/GO - Brasil
}

\begin{abstract}
RESUMO - A Experiência Ético-Formativa da Psicanálise e a Interlocução com Kant. Compreende-se com Lacan que a ética não se dispõe ao simples fato de ter obrigações, porquanto ela está intrinsecamente ligada à própria estrutura do desejo. A experiência ética funda a possibilidade de um possível rompimento sublimatório com o instituído, e está na origem motivadora de toda ação do sujeito, afirmando-se assim como uma experiência éticoformativa. A ética da psicanálise entrevê o que pode ser um bem para o sujeito, com todas as contradições, lacunas e problemas que disso provém. Tal reflexão tem por base O Seminário, livro 7 - A Ética da Psicanálise, de Jacques Lacan, obra em que o autor se põe no horizonte da ética, discutindo questões ligadas aos conceitos de das Ding, de lei moral kantiana, e de sublimação.

Palavras-chave: Psicanálise. Ética. Sublimação. Kant. Formação.
\end{abstract}

ABSTRACT - The Ethical-Formative Experience of Psychoanalysis and Dialogue with Kant. It is understood from Lacan that ethics cannot be reduced to the simple existence of obligations, as it is intrinsically linked to the very structure of desire itself. Ethical experience creates the possibility of a potential sublimatory rupture with what has been established and is the motivating source of the subject's entire action, thereby affirming itself as an ethical-formative experience. The ethics of Psychoanalysis foresees what could be of benefit to the subject, with all the contradictions, gaps and problems which that can bring. This reflection is based on Lacan's: The Seminar The Ethics of Psychoanalysis (Book VII), in which the author places himself at the horizon of ethics, discussing the concepts of das Ding, Kantian moral law and sublimation.

Keywords: Psychoanalysis. Ethics. Sublimation. Kant. Formation.

Educação \& Realidade, Porto Alegre, v. 38, n. 2, p. 399-412, abr./jun. 2013.

Disponível em: <http://www.ufrgs.br/edu_realidade> 
A Experiência Ético-Formativa da Psicanálise e a Interlocução com Kant

Distante das noções mais comuns de ética, a experiência moral em Lacan (2008), certamente não consiste em juízos e encargos de um superego incumbido de valores e normas. A ética da psicanálise se dispõe como a experiência mais paradoxal possível ao aparelho psíquico, uma vez que está referida à problemática do que pode ser considerado um bem para o sujeito, embora, ao mesmo tempo, seja uma experiência que não goza de plenitude, contrariamente, ela se constitui pela falta de objeto que a realize.

Se na economia do aparelho psíquico se presentificam ao mesmo tempo os desejos originados do princípio do prazer, assim como as tensões causadas pelo princípio da realidade, essa atualização em plano inconsciente, ocorre de modo que esses dois princípios indispensáveis já não são em si mesmos o alvo da experiência psíquica. Há algo mais determinante, e originalmente fundador de toda a sexualidade e toda atividade psíquica que, para Lacan, é da ordem de das Ding:

Esse das Ding está justamente no centro, no sentido de estar excluído. Quer dizer que, na realidade, ele deve ser estabelecido como exterior, esse das Ding, esse Outro préhistórico impossível de conhecer, do qual Freud afirma a necessidade da posição primeira sob a forma de alguma coisa que é entfremdet, alheia a mim, embora esteja no âmago desse eu, alguma coisa que, no nível do inconsciente, só uma representação representa (Lacan, 2008, p. 89).

Para o sujeito o bem consiste de certo modo na busca primária e incessante da realidade que margeia das Ding, busca que não se efetua senão de modo evanescente e sem registro na consciência (Lacan, 2008, p. 127). A impossibilidade de realização do desejo, e a tensão que dele advém, constitui o escopo da experiência moral por meio de uma atividade psíquica triplamente conflitante: a procura sempre renovada da efetivação do desejo, os encaminhamentos mais ou menos sintomáticos que o sujeito desenvolve para consegui-lo, e o investimento em um significante que represente, ainda que precariamente, um desejo primário.

No limite dessa experiência está em questão um bem, que de acordo com Lacan (2008, p. 91), trata-se de proporcionar certa satisfação rumo a das Ding, mediante o "[...] princípio do prazer que dá a lei onde se resolve uma tensão, segundo a fórmula freudiana, vinculada ao que chamaremos de os engodos bem-sucedidos - ou ainda melhor, signos que a realidade honra ou não honra", ligados ao caráter mediato e imaginário do psiquismo que se apresenta para a consciência.

Detenhamo-nos na compreensão da gênese do que pode constituir uma experiência moral para o sujeito com base na instância de um desejo fundante que, como afirma Lacan (2008) referindo-se à posição teórica de Kant, não pode ser senão de ordem noumênica. 


\section{O Retorno de Lacan a Kant: uma instância psíquica para além de todo significado}

Lacan (2008) dialoga com Kant em O Seminário, livro 7, delineando evidências de que ao psicanalista importa as implicações da razão prática kantiana, assim como os limites que essa razão estabelece para uma certa compreensão da experiência ética. Pode-se arriscar a dizer que para Kant (1991), tal experiência não se estabelece plenamente no tocante à consciência, ainda que o próprio filósofo não tenha explicitado o fato de tal modo. A experiência ética não se funda no plano da consciência do sujeito cartesiano, ou no âmbito da Estética Transcendental de Kant (1991); como se pode ver nas entrelinhas das elucidações de Lacan (2008).

A questão conduzida na Crítica da Razão Prática por Kant (2002) é a de que a consciência provinda das categorias formais da sensibilidade e do entendimento, constitui-se como um plano da sensação de autoafetação, ou ainda, como plano de conservação de um sentido interno. Nesse âmbito, o sujeito vai até onde possa realizar o esquematismo transcendental como estrutura que lhe permita não só chegar à objetividade do conhecimento a priori, mas também a elaborar uma consciência de si mesmo, símbolo do que é revelado pelo sujeito e para o sujeito. Logo, trata-se do plano da representação, ou da dimensão simbólica da ordem da linguagem. Isso significa que a ação moral não se constitui como ideal representado, mas sim, como experiência que torna presente a realidade psíquica.

Diferente do plano objetivo do conhecimento e da representação, na dimensão prática da razão, a causa noumenon de acordo com Kant (1991, p. 156-157), não é um

[...] peculiar objeto inteligível para o nosso entendimento; mas um entendimento que o possuísse como tal seria mesmo um problema, ou seja um poder de conhecer - não discursivamente mediante categorias, mas intuitivamente em uma intuição não sensível - o seu objeto, de cuja possibilidade, contudo, não poderíamos formar-nos a mínima representação. Ora, o nosso entendimento obtém deste modo uma ampliação negativa, isto é, ele não é limitado pela sensibilidade, mas, antes, a limita, enquanto denomina noumena as coisas em si mesmas (não consideradas como fenômenos). Mas ele põe imediatamente limites a si mesmo, que lhe impedem de conhecer os noumena mediante qualquer categoria e, por conseguinte, de pensá-las sob o simples nome de um algo desconhecido.

Ao referir-se ao homem como númeno, Kant (1991) em Crítica da Razão Pura aludi ao conceito do homem como ser inteligível, e não ao do homem empírico. O autor estabelece uma distinção entre phaenomena, que são entes dos sentidos, fenômenos empiricamente passíveis de entendimento, e noumena, aquilo que não pode ser pensado como 
A Experiência Ético-Formativa da Psicanálise e a Interlocução com Kant

objeto dos sentidos, viável apenas a um entendimento puro, por isso mesmo chamado por Kant de entes do pensamento.

Nessa diferenciação da razão como Kant (1991) a concebe, a face noumênica é a única que justifica a reflexão transcendental como fundamento da distinção entre um conhecimento totalmente puro e aquele a que pertencem às representações. "A reflexão transcendental que se refere aos objetos mesmos, contém, entretanto, o fundamento da possibilidade da comparação objetiva das representações em si" (Kant, 1991, p. 159), sendo assim, muito diversa do conhecimento ao qual as representações pertencem. Dito de outro modo, as coisas que os sentidos e o entendimento humano representam, são antes, apenas fenômenos, uma aparência. No entanto, na vida noumênica pode-se olhá-las como coisas reais, como objeto das representações.

Para Kant (1991) a sensibilidade não é o único modo possível de intuição, e a causa noumenon é um conceito limite que está para além de toda intuição sensível, essa causa não deve absolutamente ser pensada como representação. Com efeito, o noumenon deve ser pensado em si mesmo como meramente inteligível, cuja possibilidade conceitual precisa ser tomada como algo indeterminado, ou em sentido meramente desconhecido.

É possivelmente a causa noumenon que funda, na obra kantiana, a dimensão que pode ser considerada como uma instância psíquica. A experiência moral é afirmada ao passo que se possa admitir o sujeito transcendental como aquele que prescinde de toda sensibilidade e que subsiste em uma unidade problemática. O sujeito transcendental convoca a seu modo o universo simbólico, entretanto, como uma definição, não é nada. Pode-se dizer que é inteligível puro, é da ordem do incondicionado, constitui-se hipoteticamente.

Para alguns contemporâneos de Kant, pensar essa unidade hipotética, para além de toda experiência possível, não parece razoável, a começar pelo caráter de inescrutabilidade que a questão condensa nela mesma. No entanto, Kant (2002) insiste na plausibilidade desse foro no âmbito de uma vontade pura, causa primeira da moralidade no ser humano. De outra parte, para Lacan (2008, p. 70), parece ser exatamente essa questão controversa que lhe causou interesse e o instigou a dizer que Kant "[...] mais do que qualquer outro, entreviu a função de das Ding, embora, abordando-a apenas pelas vias da filosofia da ciência". A instância psíquica hipotética, ao fim e ao cabo, é o fundamento da experiência ética, na origem é condição de possibilidade para se pensar a razão prática, e com ela, a questão do bem numa perspectiva kantiana.

O objeto essencial da economia psíquica do sujeito, nomeado por Lacan (2008) de das Ding, no seu ponto de partida “[...] logicamente e, da mesma feita, cronologicamente, da organização do mundo no psiquismo - se apresenta, e se isola, como termo de estranho em torno do qual gira todo o movimento da vorstellung" (Lacan, 2008, p. 74), em certo sentido, não se distancia da compreensão kantiana de que há no sujeito uma dimensão lógica da autoconsciência, do Eu penso. E, sobretudo, 
subsiste para além desta, uma dimensão do inteligível puro, como ente problemático que se subtrai à linguagem, e, ao mesmo tempo, ordena a vontade ${ }^{1}$.

Do ponto de vista da psicanálise, se é possível atribuir algo à causa noumenon kantiana, é somente que ela é uma realidade psíquica. Uma definição desse tipo, contudo, não foi conferida pelo próprio Kant, que em coerência com as possibilidades de seu tempo e de sua obra, deixou a questão em aberto. Como afirma Lacan (2008), Kant concebe a ação segundo máximas que se regulam por uma lei em que o sujeito moral é convidado a realizar uma outra natureza. "Trata-se, portanto, da referência mental a uma natureza na medida em que esta é ordenada por leis de um objeto construído por ocasião da questão que nos colocamos sobre a matéria de nossa regra de conduta" (Lacan, 2008, p. 97).

Acrescentando, pode-se dizer que o psiquismo humano é chamado a atualizar sua natureza prática, ou a moralidade que lhe é peculiar, embora, sob a condição de assunção por parte do sujeito. Kant (2002, p. 178) afirma em Crítica da Razão Prática que "[...] a lei moral é o único fundamento determinante da vontade pura”. A vontade deve guiar-se pela lei moral, não em razão de máximas particulares, e muito menos por motivações exteriores. Veremos a seguir que a motivação é dada, antes, por uma lei original de autorregulação, uma lei que abarca a autopreservação de certa economia psíquica.

Importa elucidar os horizontes kantianos ligado àquilo que Lacan (2008, p. 91) chama de o bom objeto, na obra de Kant, isso se refere à possibilidade de agir segundo a máxima moral: "Age como se a tua máxima devesse servir ao mesmo tempo de lei universal de todos os seres racionais" (Kant, 1995, p. 82). Também para Kant (2002), não se trata de agir segundo regras de conduta estabelecidas, mas fazê-lo em acordo com a lei moral, que é a máxima moral capaz de garantir a vida e a liberdade ao mesmo tempo.

Lacan, (2008, p. 226-228) em sua obra, cita exemplos elucidativos apresentados por Kant acerca da relação do sujeito com a lei moral como propedêutica de um bem que no limite, obriga a renúncia do próprio gozo, em favor do lugar autêntico da ética como experiência sublimada em sentido particularmente kantiano. Lacan (2008) enuncia o alcance e a originalidade das proposições kantianas, ao mesmo tempo em que as desarranja quanto a possibilidade de

[...] demonstrar o peso da Lei, formulada por ele como ra-
zão prática, como impondo-se em termos puros de razão,
isto é, para além de todo afeto, tal como ele se expressa,
patológico, ou seja, sem nenhum motivo que interesse ao
sujeito (Lacan, 2008, p. 226).

Para efeito da presente discussão, vale dizer que para Kant (1995), uma máxima particular é o princípio subjetivo da ação. Ela contém a regra prática que determina a razão em conformidade com as condições do sujeito, e, até mesmo, segundo sua ignorância ou inclinações, portanto, é o princípio segundo o qual o sujeito age. Diferentemente, a lei

Educação \& Realidade, Porto Alegre, v. 38, n. 2, p. 399-412, abr./jun. 2013. 403

Disponível em: <http://www.ufrgs.br/edu_realidade> 
A Experiência Ético-Formativa da Psicanálise e a Interlocução com Kant

moral ou máxima moral é o princípio objetivo da vontade, válida para todo o ser racional é o princípio segundo o qual ele deve agir. Quando o imperativo de agir é determinado pela vontade, apresentando uma razão objetivamente necessária por si mesma, desvinculada de qualquer finalidade relativa ao interesse do sujeito, e também sem qualquer imposição exterior ao sujeito, ela é o que Kant (1995) chama de imperativo categórico.

O modo como a vontade se dirige para a realização de um fim, é que define o imperativo de agir como categórico, neste caso, a ação deve ser objetivamente necessária sem qualquer propósito (Kant, 1995). Em Crítica da Razão Prática, Kant (2002) demonstra que no axioma da lei moral, o que importa é o caráter formal da vontade. O ser racional ao representar suas máximas como leis universais práticas, de acordo com Kant (2002, p. 45), “[...] somente pode representá-las como princípios que contém o fundamento determinante da vontade não segundo a matéria, mas simplesmente segundo a forma".

Determinar um objeto segundo a forma significa concebê-lo de modo puramente lógico, estruturando-o apenas pelo pensamento. Por isso, a sentença kantiana, "[...] age de tal modo que a máxima de tua vontade possa sempre valer ao mesmo tempo como princípio de uma legislação universal" (Kant, 2002, p. 51), é concebida pelo filósofo do ponto de vista da lei moral objetiva. Essa lei preserva e orienta aquilo que a subjetividade sozinha não poderia fazê-lo: garantir a existência do plano do deve ser, em consonância com as leis da liberdade.

A perspectiva que se pode adotar a partir de Kant é a de conceber a experiência ética como uma consequência necessária das circunstancias sob as quais a razão constitui-se como prática. Ainda que a esfera da vontade pareça paradoxal na relação com a lei moral, os laços que ligam o homem noumênico e o homem empírico tornam-se mais claros, à medida que se possa aderir à compreensão kantiana de que a vontade livre é que estabelece a lei universal, ao mesmo tempo, tal vontade não é determinável por qualquer objeto ou causa alheia à lei. Segundo Kant (1995) em sua obra Fundamentação da Metafísica dos Costumes, isso é possível,

[...] porque o mundo inteligível contém o fundamento do mundo sensível, e portanto também das suas leis, sendo assim, com respeito à minha vontade (que pertence totalmente ao mundo inteligível), imediatamente legislador e devendo também ser pensado como tal, resulta daqui que, posto por outro lado me conheça como ser pertencente ao mundo sensível, terei, como inteligência, de reconhecerme submetido à lei do mundo inteligível, isto é, à razão, que na ideia de liberdade contém a lei desse mundo, e portanto à autonomia da vontade; por conseguinte terei de considerar as leis do mundo inteligível como imperativos para mim e as ações [sic] conformes a este princípio como deveres (Kant, 1995, p. 104). 
Nesse sentido, a própria possibilidade do imperativo categórico impõe questões fundamentais do pensamento kantiano que abalam toda a condição natural do homem, dando primazia à sua destinação prática ou moral.

Pode-se dizer que se há uma vontade pura, noumênica, incondicionada, é ela que move a experiência ética. Entretanto, a questão requer maiores esclarecimentos, pois Kant (2002) não postula o dever com a lei, como um dever em si mesmo, a experiência ética está ligada originalmente à determinação do ato pela vontade livre. A dimensão da vontade para ele é independente das determinações da natureza, bem como diferente da simples capacidade de escolha ou arbítrio. É preciso pensá-la paradoxalmente como capacidade humana de autodeterminação em consonância com a lei moral. Nesse sentido, a vontade é aquilo que funda o dever com a lei moral ${ }^{2}$.

A dimensão ética para Kant (2002) não é o reino da experiência plena, antes, é problemática e padece de vicissitudes que, segundo a compreensão do filósofo, não obstante o aprazimento decorrente da ação moral, o sujeito permanece incomodado no fundo de si mesmo por um sentimento de prazer e de dor. No entanto, ele contesta que esses sentimentos, cuja motivação é inteiramente sensível, possam servir de fundamento para uma ética digna de significado. Nesse ponto, indubitavelmente, distanciam-se Lacan e Kant, já que para Lacan (2008) as motivações que o filósofo quer suprimir do sujeito são exatamente os móbiles da ação ética.

A psicanálise leva em consideração o campo obscuro, primário e motivador dos afetos (Lacan, 2008), ela abre uma infinidade de questões que não seriam pertinentes ao universo do filósofo alemão. Em Crítica da Razão Prática, Kant (2002) menciona a questão do prazer e do desprazer, mas não os considera de modo algum como móbil da vontade pura, para autor, esses sentimentos só podem ser conhecidos empiricamente, não são válidos como lei moral, ainda que essa lei conflitante seja o fundamento determinante do amor de si mesmo, ou de qualquer representação que se possa fazer dele. Reforçam-se assim as razões que integram o ponto de vista de Lacan (2008) acerca das proposições kantianas e sua inclinação à sublimação excessiva do objeto (Lacan, 2008, p. 134).

Pode-se dizer com alguma ousadia, e com base no universo da psicanálise, que nas proposições kantianas (1995 e 2002), a sublimação segue uma tendência que não é da ordem do gozo, mas da ordem do desejo. É da rubrica de um desejo abnegado, em favor da preservação de si mesmo - como dignidade. Este é um ponto fundamental do pensamento kantiano que Lacan sem dúvida não ignora em seu seminário.

Na obra Fundamentação da Metafísica dos Costumes, Kant (1995) postula acerca do valor intrínseco e motivador de toda ação humana, ressaltando que

[...] no reino dos fins tudo tem ou um preço ou uma dignidade. Quando uma coisa tem um preço, pode-se pôr em vez dela qualquer outra como equivalente; mas quan-

Educação \& Realidade, Porto Alegre, v. 38, n. 2, p. 399-412, abr./jun. 2013. 405 
A Experiência Ético-Formativa da Psicanálise e a Interlocução com Kant

do uma coisa está acima de todo preço, e portanto não permite equivalente, então tem ela dignidade. O que se relaciona com as inclinações e necessidades gerais do homem têm um preço venal; aquilo que, mesmo sem pressupor uma necessidade, é conforme um certo gosto, isto é a uma satisfação no jogo livre e sem finalidade das nossas faculdades anímicas, tem um preço de afeição ou sentimento (Affektionspreis); aquilo porém que constitui a condição só graças à qual qualquer coisa pode ser um fim em si mesma, não tem somente um valor relativo, isto é um preço, mas um valor íntimo, isto é dignidade (Kant, 1995, p. 77).

A ética kantiana é cética com relação aos afetos e motivos contingentes, tanto quanto, com as motivações impostas alhures. Nesse aspecto ela pode, por exemplo, constituir-se avessa à moral cristã, caso esta moral seja concebida de modo relativo. Isto é, concebida como moral sintetizadora da obediência a Deus e da primazia do bem dos outros sujeitos, como único móbil da ação ética.

A fim de situá-la melhor, pode-se dizer que na ética kantiana, o outro, talvez não deva ser considerado na ação como objeto primeiro, mas segundo. Espera-se aqui delimitar esse objeto segundo, não no tocante ao grau de importância, mas à hierarquia motivadora da ação. Por certo, um ser humano não deve matar um outro ser da sua espécie por respeito à vida desse outro, mas movido, sobretudo, pela sua própria dignidade moral. Em outras palavras, ele não deve cometer tal ação em respeito à lei moral, que é a expressão mais acabada do pleno uso da sua vontade livre.

Lacan (2008) encaminha a sua interlocução com Kant tendo em vista que no contexto desse filósofo, a sublimação pode ocorrer exatamente no rastro desta radicalidade em que há uma vontade incorruptível vinculada à lei moral, que se desdobra para todo possível sujeito ético. Tal sujeito pode assumir quaisquer consequências, sacrificar a si mesmo se for o caso, em favor do valor íntimo da ação, que pode ser traduzida em certa medida como uma experiência de satisfação freudiana.

Esse contexto traduz, em parte, o que pode ser considerado uma experiência ética para o filósofo alemão. $\mathrm{O}$ fato de a ação moral apresentar-se como satisfação da natureza prática do sujeito, decerto, levou Lacan (2008, p. 132-133) a expressar sua compreensão de que para a moral kantiana, "[...] o peso do princípio ético puro e simples, a prevalência possível do dever como tal para com e contra tudo, isto é, para com e contra tudo [é] concebido justamente como vitalmente desejável".

Em outra ordem de proposições, Lacan $(2008$, p. 95) entende que a questão do bem não se estabelece a priori, pelo princípio de uma lei essencialmente sublimada, mas sim, pelo caminho insólito em que a subjetividade "[...] busca inconscientemente nas estruturas sociais", e dá a lei estritamente ligada à própria estrutura do desejo. Das Ding alimenta a economia do aparelho psíquico, e o faz de modo inacessível. 
As saídas que o aparelho psíquico busca para lidar com as tensões fundadas no inconsciente, remete, em certa medida, ao que Freud (2004), em Pulsão e Destinos das Pulsões considera como ambivalência, uma relação de forças entre amor e ódio, geradora de um campo desestabilizador que invoca uma economia de substituição para a satisfação da pulsão de modo a recalcá-la. Advém desse contexto, a "[...] sublimação como um modo de satisfação possível da pulsão” (Lacan, 2008, p. 135).

A propósito da sublimação, Lacan (2008, p. 131) não se detém nessa economia de substituição, ele amplia o conceito, fazendo objeção à tendência de conceber a sublimação tão somente como "[...] um esforço de reparação simbólica das lesões imaginárias ocasionadas na imagem fundamental do corpo materno". Nesse contexto, o autor contrapõe-se à perspectiva de Melanie Klein, considerando-a corroboradora de certo mito ligado ao "[...] registro da explosão mais ou menos transitória de supostos dons artísticos" (p. 131), introduzindo outra trajetória que delineia o problema da sublimação ligado a possibilidades criadoras em que a arte não é a única forma.

O processo criativo advindo da sublimação não se constitui senão como resíduo daquilo que é incessantemente buscado como fundamento de um bem. Esta busca - central para se pensar a ética no sentido mais amplo - é uma ambição psíquica contraditória que está para além do princípio do prazer. "Pois, segundo as leis do princípio do prazer, o significante projeta nesse para além a equalização, a homeostase, a tendência ao investimento uniforme do sistema do eu como tal - fazendo-o faltar" (Lacan, 2008, p. 145). A falta alimenta a procura nas vias do significante.

De significante em significante, “[...] o princípio do prazer regula por meio de uma lei do engodo” (Lacan, 2008, p. 145) o nível de tensão do aparelho psíquico. A procura vital do reencontro com a Coisa ganha forma e expressão por meio dos signos. É essa relação do homem com o significante, à proporção que ele modela esse significante à imagem tosca do objeto de desejo originário, que torna possível o ensejo da criação de um objeto.

A noção de criação tem a ver com um status no qual a experiência sublimada eleva o objeto criado, ascendendo-o "[...] à dignidade da Coisa" (Lacan, 2008, p. 137), embora, tal objeto, jamais se confunda de fato com ela. Lacan (2008, p. 147), propõe uma reflexão em que a rede significante viabiliza o que é significável, mas "[...] de nada particularmente significado". É o vazio da função significante que exprime “[...] a existência do vazio no centro do real que se chama a Coisa, esse vazio tal como ele se apresenta na representação, apresenta-se, efetivamente, como um nihil, como nada" (p. 148).

Para Lacan (2008) a dimensão simbólica estende seu domínio efetivamente, seja em relação ao caráter ético-formativo, ou em qualquer outra instância humana. A questão está no plano da relação do homem com o significante, "[...] as coisas do mundo humano são coisas de um 
A Experiência Ético-Formativa da Psicanálise e a Interlocução com Kant

universo estruturado em palavras, que a linguagem, que os processos simbólicos dominam, governam tudo" (Lacan, 2008, p. 59). Entretanto, Lacan (2008) não se detém na compreensão segundo a qual o homem cria o mundo simbólico, essencialmente, para seus próprios suportes psíquicos. O fruto dessa experiência psíquica que "[...] está no âmago da economia libidinal” (p. 138), precária e provisoriamente inscrito como objeto sublimado, deixa de ser apenas um meio para o gozo e ganha a condição de um fim em si mesmo.

Lacan (2008, p. 139) indica que, se "[...] na análise o objeto é um ponto de fixação imaginário dando, em qualquer registro que seja, a satisfação de uma pulsão", na experiência de sublimação, o objeto é totalmente outra coisa, torna-se de algum modo livre, disponível, exatamente pela mudança da relação entre o objeto e o desejo que o gerou. Tal objeto torna-se, deveras, isento do preço a pagar com as representações do objeto sexual original. Especialmente nesse ponto Lacan (2008) ultrapassa a perspectiva de Melanie Klein, considerando-a tributária da noção que põe fundamentalmente no corpo da mãe o ciclo de possibilidades de toda sublimação.

A problemática que se põe é a de que a obra sublimada não se constitui para nenhuma necessidade finalística fora dela mesma, ela é destituída de quaisquer objetivos mais ou menos elevados que se possa atribuir-lhe. Não se pode nomear uma obra sublimada, mas, tão somente, implicar-se com ela, posição que revela em alguma medida, o alcance e o destino da sublimação na experiência ética. Segundo Lacan (2008, p. 68), “[...] o que é buscado é o objeto em relação ao qual o princípio do prazer funciona. Esse funcionamento é, no tecido, na trama, o suporte a que se refere toda a experiência prática".

A relação da experiência sublimatória com a formação do sujeito ocorre no plano da relação do objeto com o desejo, e não pode absolutamente ser delimitada hic et nunc, senão em um movimento de superfície que pouco expressa a realidade psíquica do sujeito. Reforça-se assim, o fato de que não se pode atribuir a tal experiência ético-formativa implicada na sublimação qualquer função social, a não ser talvez, a do espanto, a da criação em sentido irrestrito.

O inusitado exemplo da coleção de caixas de fósforos, explorado por Lacan (2008) em O Seminário, livro 7, elucida como algo novo pode constituir-se para além de todo sentido que se possa atribuir a objetos triviais como as caixas de fósforos. A obra sublimatória projeta-se em grande medida, como o próprio gozo, inseparável da experiência de prazer subjetiva que lhe deu vida. Com referência a essa disposição da sublimação, Lacan (2008) avança no sentido da elevação do objeto à dignidade da Coisa. É legítimo considerar nesse ponto que há uma inseparabilidade entre sujeito e objeto, já que ambos constituem ao mesmo tempo, uma experiência única. Sujeito e objeto na experiência de sublimação são diferentes faces de um mesma realidade, lacunar e simbolicamente precária, que na origem inatingível pela consciência, são expressão mal acabada de das Ding. 
Pode-se compreender que a sublimação, por vezes, permite “[...] inventar um objeto numa função especial, que a sociedade pode estimar" (Lacan, 2008, p. 138), contudo, é preciso considerar a condição francamente paradoxal da obra sublimatória que não se revela sempre, e necessariamente, no registro de uma obra de cultura. De acordo com Lacan (2008), a sublimação está remetida à relação do sujeito com o significante, quanto mais esse significante representa atualização às margens de das Ding. Para o autor,

[...] trata-se do fato de o homem modelar esse significante e introduzi-lo no mundo - em outros termos, de saber o que faz modelando o significante à imagem da Coisa, enquanto que esta se caracteriza pelo fato de que nos é impossível imaginarmo-la para nós. É aí que se situa o problema da sublimação (Lacan, 2008, p. 152).

A sublimação pode, porventura, se afirmar por meio do "[...] caráter completamente gratuito, proliferante e supérfluo, quase absurdo” (Lacan, 2008, p. 140) de uma obra. Por outro lado, em sua envergadura como processo inconsciente a sublimação atualiza marcas, indica uma direção psíquica em que o sujeito encontra a sua motivação, menos no objeto sublimado em si, e mais na Coisa que subsiste àquele objeto. $\mathrm{O}$ objeto sublimado, na condição de objeto metonímico, decorre de um excesso afetivo que extravasa do inconsciente. Muitas vezes ele se expressa de modo controverso, pondo em questão o instituído, uma vez que na sua origem ele não tem nenhum compromisso com o estabelecido.

Torna-se flagrante a ingenuidade de dar às inovações postas a priori o estatuto de novo, ou de criação. Não é exatamente a suspensão de todo significado já existente que põe a criação em outra ordem de questões? A problemática da criação tem a ver com um im-possível delineamento do "[...] significante à imagem da Coisa” (Lacan, 2008, p. 152), ainda que a criação desvelada pela experiência sublimatória seja uma réstia da realidade primordial, que, como insiste Lacan (2008), se é passível de registro, de simbolização, o é apenas em campos já domesticados.

De todo modo, esse real chamado das Ding incomoda desde sempre pelo fato de escapar à domesticação completa. O objeto sublimado constitui-se reveladoramente novo, à medida que quase sempre transgride à moral pré-concebida com pretensões de verdade, abalando assim as respostas dadas pelo universo simbólico. A provocação posta à dimensão formativa do ser humano está, sobretudo, no fato de que não se pode conceber a ética da alteridade, ou a ética da abertura face ao outro, senão em um campo ético-formativo que inclua em si mesmo a natureza indomesticável da obra sublimatória.

\section{A Ética para Além da Consciência: considerações finais}

O Seminário, livro 7 de Lacan (2008), traça um esvaziamento radical da moral positiva ao conceber de outro modo o lugar da ética como

Educação \& Realidade, Porto Alegre, v. 38, n. 2, p. 399-412, abr./jun. 2013. 409

Disponível em: <http://www.ufrgs.br/edu_realidade> 
A Experiência Ético-Formativa da Psicanálise e a Interlocução com Kant

experiência originária, ligada ao campo obscuro e imprevisível do inconsciente. A ética da psicanálise, como ética do desejo não se afirma diante de significações imediatas, mas é fundamentalmente a posteriori. Há algo na ordem ética que a Psicologia, a Filosofia, a Educação, ou qualquer outro saber não pode acessar senão superficialmente. Há algo que faz com que ninguém possa atribuir a outrem o que já não lhe pertença de algum modo em forma de pulsão, no limiar de das Ding.

Se a ética da psicanálise, de um lado padece da impossibilidade de definição, de outro concorre para a dimensão livre do sujeito, e suas possibilidades de criação e rompimento sublimatório com o instituído. A psicanálise dá abertura ao fato de que a ética não está remetida ao que é moralmente bom ou ruim, mas ao que pode ser um bem para o sujeito, com todas as contradições, lacunas e problemas desse contexto provenientes. E, nesse aspecto, com certeza, Lacan e Kant concordariam.

Uma problemática bastante aclamada nas discussões acerca da formação humana é a de como conceber a ética da alteridade, de modo a articulá-la no mundo, entre os homens, e nas instituições. Questões dessa natureza por vezes não são plausíveis ante as possibilidades da psicanálise, porque não se trata de tornar a ética, a criação, a sublimação, em realidades conscientes e positivas nos processos formativos do sujeito. Se a formação humana passa pela realidade psíquica, então ela tem implicações com as questões postuladas por Lacan (2008, p. 94-95), ao afirmar que

[...] a ética não é o simples fato de haver obrigações, um laço que encadeia, ordena e constitui a lei da sociedade. [...] Ela começa no momento em que o sujeito coloca a questão desse bem que buscara inconscientemente nas estruturas sociais - e onde, da mesma feita, foi levado a descobrir a ligação profunda pela qual o que se apresenta para ele como lei está estreitamente ligado à própria estrutura do desejo.

Por esse caminho não se pode admitir a experiência ético-formativa, senão na anterioridade das questões instituídas, ela está, mais precisamente, fora do sentido estabelecido. Ela coincide com a problemática da sublimação, sem que se trate, todavia, de uma substituição significante carregada de estruturas sobredeterminadas. Trata-se da criação do objeto, de acordo com Lacan (1999, p. 240), à medida que ele é um objeto metonímico de um tipo particular e radical, ligado a registros pulsionais que representam "[...] no imaginário, aquilo que sempre se furta, aquilo que se induz de uma certa corrente de fuga do objeto para o imaginário, em razão da existência do significante". Toda experiência ético-formativa lida com a incerteza e com as implicações de uma referência originalmente fálica e posteriormente criadora, que está para além do imaginário, ou ainda, às expensas de Kant (1991), pode-se dizer que uma experiência ético-formativa lida com uma instância psíquica problemática que está para além de toda representação. 
A temática da ética e a da formação humana vistas de tal modo, promovem no espírito da modernidade o que há de mais herético e inaceitável para esse próprio tempo, suas ciências e saberes: que é a ausência de significado objetivamente claro e evidente da psykhé humana. Ainda que Kant (2002) no seu tempo, não tenha fundado precisamente a questão da realidade psíquica nos temos do inconsciente, posto não ser esse o seu télos, Lacan (2008) por sua vez, ao dialogar com o filósofo de Königsberg, entreviu-lhe a envergadura crítica que apresentava algo novo acerca de sua época, e acerca de uma ética que pudesse superar as tradicionais relações de causa e efeito. Lacan distinguiu no pensamento de Kant a importância da causalidade noumênica, justamente, destituída de certa objetividade, subsistindo como região obscura, que não se apresenta senão como impulso da vontade, fonte de toda atividade psíquica. Um encontro entre psicanálise e Kant que propícia a crítica epistemológica acerca dos limites da autonomia da consciência.

A psicanálise põe a experiência moral e a formação humana em uma ordem de questões ligadas à sexualidade, ao inconsciente, e às peculiares antinomias e desordens da organização do psiquismo. Lacan (2008), por sua vez, abre possibilidades de reflexões desafiadoras acerca da precária objetividade inerente mesmo àquela realidade primeira, irredutível e inseparável de todo o psiquismo humano. Sobre essa realidade, deveras, a atividade psíquica busca reencontrar o que nunca foi perdido, sente a falta do que nunca teve, e elabora o que não sabe. Não será essa também, alguma vez, a sina do Poeta?

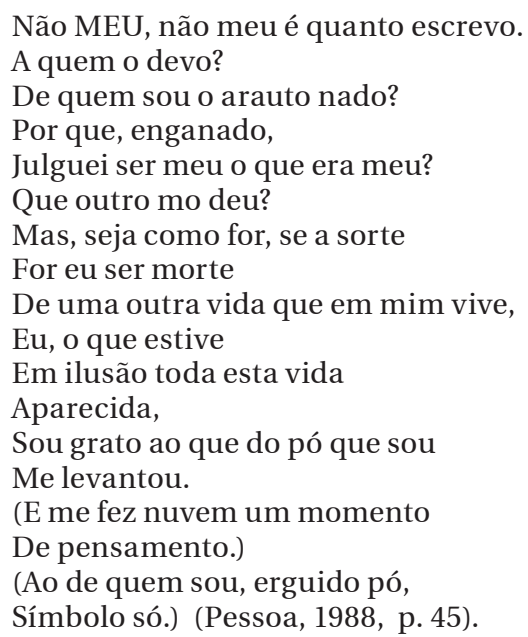

Recebido em 07 de novembro de 2012 Aprovado em 07 de abril de 2013

\section{Notas}

1 A vontade é o princípio inerente ao homem e que lhe permite tornar-se moral. Para Kant $(1995,2002)$, assim como o entendimento termina onde cessam os 
A Experiência Ético-Formativa da Psicanálise e a Interlocução com Kant

conceitos, a vontade livre termina somente onde cessa a humanidade. Como postula Kant (1995, p.9), “[...] a vontadeé uma espécie de causalidade dos seres vivos, enquanto racionais, e liberdade seria a propriedade desta causalidade, pela qual ela pode ser eficiente, independente de causas estranhas que a determinem." A dimensão da vontade é independente das determinações da natureza, é capacidade humana de arbítrio em consonância com a lei moral. Paradoxalmente, a vontade é a fonte humana que obriga, ou institui o dever, como princípio da ação autônoma. Kant (2002, p. 178) afirma em Crítica da Razão Prática que "[...] a lei moral é o único fundamento determinante da vontade pura". Portanto, a vontade guia-se pela lei moral por motivo dela mesma e não em razão de qualquer outro motivo externo ou particular. Os princípios da lei moral tornam objetivamente obrigatórios, ou seja, ligados ao dever, a própria vontade que não carece de qualquer outra causa para realizar essa prescrição.

2 De acordo com Kant (2002), em Crítica da Razão Prática, o dever não é uma determinação antropológica, mas uma disposição necessária à economia da razão prática, ele afirma o respeito pela lei moral, que é o fundamento determinante da vontade pura. O dever é necessário exatamente para balizar os interesses postos pelos motivos sensíveis e particulares que se contrapõem à vontade pura. $\mathrm{O}$ conflito entre os interesses subjetivos e os fundamentos objetivos do sujeito integram uma vontade que, apesar de patologicamente afetada pela sujeição à lei, não é de modo algum patologicamente determinada, por isso, é paradoxalmente chamada de vontade livre. Para Kant (2002, p. 130), “[...] a ação que, de acordo com essa lei e com exclusão de todos os fundamentos determinantes da inclinação, é objetivamente prática chama-se dever, o qual, em virtude dessa exclusão contém em seu conceito uma necessitação prática, isto é, uma determinação a ações, por mais a contragosto que elas possam acontecer".

\section{Referências}

FREUD. Sigmund. Pulsões e Destinos da Pulsão. In: FREUD. Sigmund. Escritos sobre a Psicologia do Inconsciente. Coord. geral da tradução, Luiz Alberto Hanns. Rio de Janeiro: Imago, 2004. P. 133-171.

KANT, Immanuel. Crítica da Razão Pura. 4. ed. Tradução de Valério Rohden e Udo B. Moosburger. São Paulo: Nova Cultural, 1991. (Os Pensadores; v. 1)

KANT, Immanuel. Crítica da Razão Prática. Tradução de Valério Rohden. São Paulo: Martins Fontes, 2002.

KANT, Immanuel. Fundamentação da Metafísica dos Costumes. Tradução de Paulo Quintela. Lisboa: Edições 70, 1995.

LACAN, Jacques. O Seminário: livro 5: as formações do inconsciente. Texto estabelecido por Jacques-Alain Miller. Tradução de Vera Ribeiro; revisão de Marcus André Vieira. Rio de Janeiro: Jorge Zahar, 1999.

LACAN, Jacques. O Seminário: livro 7: a ética da Psicanálise. Texto estabelecido por Jacques-Alain Miller, versão brasileira de Antônio Quinet. Rio de Janeiro: Jorge Zahar, 2008.

PESSOA, Fernando. Os Melhores Poemas de Fernando Pessoa. 4. ed. Seleção de Teresa Rita Lopes. São Paulo: Global, 1998. (Os Melhores Poemas)

Simone Alexandre Martins Corbiniano é doutoranda pela Universidade Federal de Goiás (UFG), Goiânia/Goiás. Membro do Grupo de Estudos e Pesquisas de Filosofia e Educação da Faculdade de Educação (UFG). E-mail: simone@antaresbr.com 